\title{
THE ROOTS OF IUGS
}

by

\author{
James M. Harrison
}

The quadrennial International Geological Congress first met in Paris one hundred years ago this year. IUGS, its current sponsoring union and one of the three largest scientific unions in the world, was founded only seventeen years ago. Dr. James M. Harrison, first President of IUGS, blends historical perspective with personal reminiscences in a candid account of the origins of IUGS and its unique "cart before the horse" relationship with the Congress.

When the new Secretary General of IUGS asked if I would help commemorate the launching of Episodes with a sketch of IUGS' initial "episode" - its inauguration, I suddenly realized how sporadic my documentation of the event had been. Most of the notes, transcripts and photographs I thought I once had have either been lost or misplaced. What remained was largely dog-eared, irrelevant and obsolete.

I mention this at the start for two reasons: firstly, to emphasize that this review does not purport to be a comprehensive history of the origins of the Union; secondly, to express my gratitude to some people whose records and recollections have proved invaluable. Specifically, I have in mind Professor Arne Noe-Nygaard who was President of the 21 st International Geological Congress in Norden, Mr. KarlAlbert Lindbergson who served as Chairman of the working group charged with the task of bringing the "latecomer" among international scientific unions into existence, and Dr. Michel Batisse, currently a Deputy Assistant Director General at Unesco, who contributed much factual data from his remarkable store of knowledge. In addition, the Geological Survey of Finland was kind enough to forward relevant materials prepared in December of 1960 by Vladi Marmo who was then its Director and one of the active founders of the Union. I am grateful also to the Secretariat of IUGS who gave me complete access to their files.

\section{Engines Astern}

The first rumblings about the desireability of geologists to form a specialized union go back to 1922 and the International Geological Congress held in Belgium. The matter was dropped rather quickly once the argument that the IGC itself served as an international scientific organization was put forward. This, coupled with the fact that the Congress had met reasonably regularly ever since its founding meeting in 1878, seemed to satisfy the geological fraternity.

At the first Congress to be held following the Second World War (London, 1948), the feasibility of a geological union was again raised, primarily by Unesco representatives. (Unesco's Director General at the time was Sir Julian Huxley, a descendant of Thomas $\mathrm{H}$. Huxley, one of the founders of the first Congress 70 years before.) It was Dr. Joseph Needham who spoke on behalf of Unesco, because his recent successor as Director of Natural Sciences, Dr. Pierre Auger, was unable to attend.* He described Unesco's need to deal with scientific disciplines through formal channels, pointing out that geologists were the only important scientific group with whom Unesco had no direct links and that the success of its Science division depended on this type of contact. Furthermore, Unesco was able to support and provide contracts to those Unions which adhered to the International Council of Scientific Unions (ICSU), which had succeeded the International Research Council in 1931.
In the long discussions that followed, strong support was shown for the concept of a geological union, but there were equally strong reservations about the long-term impact that financial support from Unesco might have: would it be possible for the Union to act independently? The final vote, carried by a large majority, opted for postponing the formation of a union and establishing instead a "Bureau" of the IGC which could, if necessary, advise Unesco.

Four years later at the 19th Session of the IGC (Algjers, 1952) the Council was asked once again to consider the question of a union. Both Professor H.M.E. Schürmann of the Netherlands in a discussion paper and Jean Goguel of France in some draft statutes presented rather strong arguments for the need of a union. Their arguments were virtually crushed by a member of the U.K. delegation (later a strong proponent for the Union) who declared that "he had been unable to ascertain even one sound reason for the formation of such a Union".

The thorny question of the Union-Congress relationship came to the fore in these deliberations. In the end, a large majority backed the proposal of Professor H.H. Read (President of the previous Congress) that each country form a National Committee for Geology and that the members of the existing Bureau take appropriate initiatives to accomplish this. Once the National Committees were formed, it was argued, there would be no further need to create a union.

\section{Full Speed Ahead}

The climate changed in Norden at the 21 st Congress (1960), sponsored by the five Nordic countries. By then the spectacularly successful International Geophysical Year, run by the International Union of Geodesy and Geophysics, had received acclaim from the scientific world at large. There had been no formal geological participation in it. By 1960, 13 international scientific unions comprised the International Council of Scientific Unions. Geology was conspicuous by its absence. Many geologists were becoming concerned by this evidence of IGC's inability to act effectively between Congresses.

The third circular put out by the Organizing Committee for the Norden Congress included a proposal from Switzerland and Holland to establish a committee to study the feasibility of an International Geological Union. The United Kingdom even went a step further by asking the Council at Norden to consider a specific proposal for the formation of an International Union and by drafting appropriate statutes. As it happened, discussions in the Bureau concentrated almost entirely on this proposal. Council even established a "working committee" to debate the pros and cons of the proposal with the Bureau members. The fact that a Union would have sources of funds from national members and also from the

* In the Proceedings of the meeting, Dr. Auger's name is misspelled as "Roget". 


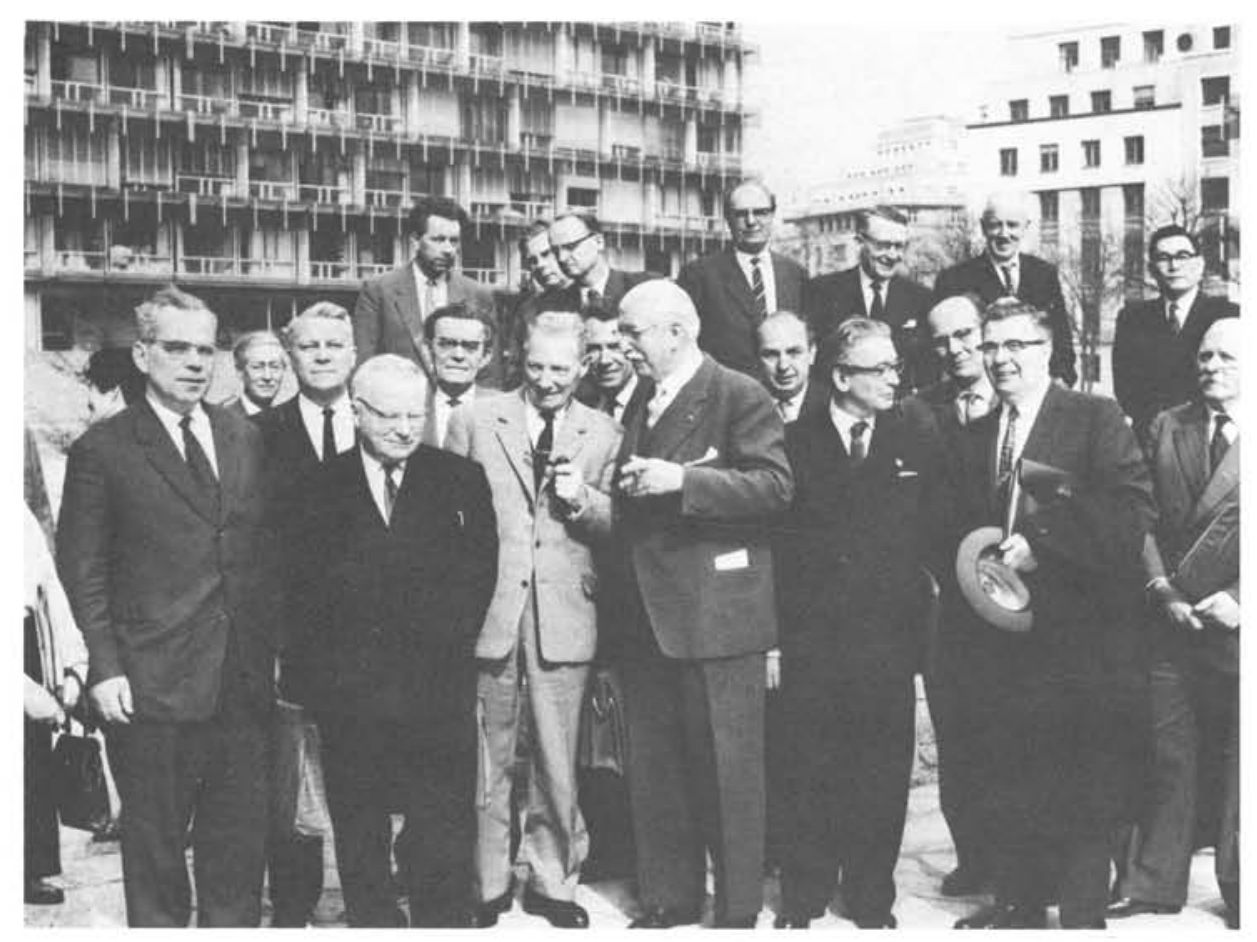

A group gathered in front of Unesco headquarters in Paris during the March 1961 'founding' meeting of the Union. In front, left to right: N. Beliaevsky, USSR, W.P. van Leckwijck, Belgium, I. Gorsky, USSR, F. Prantle, Czechoslovakia, J. Lombard, France, M. Batisse, Unesco, H.M.E. Schürmann, Netherlands, G. Castany, Tunisia, A. Codarcea, Roumania, A. Thiadens, Netherlands, Piret, U.S.A., M. Collignon, Madagascar. At back, left to right: L. Vonderschmitt, Switzerland (between Beliaevsky and van Leckwijck); standing, far back row: J.A. Dons, G.H.R. von Koenigswald, Netherlands, H. Kupper, Austria, H.J. Martini, Federal Republic of Germany, K.A. Lindbergson, Sweden, L. Hawkes, U.K. and S. Hori, Japan. (Photo: Courtesy Unesco)

Unesco subvention to ICSU, thus enabling it to help finance Congress Commissions and Committees, stood undisputed. The Bureau finally proposed to Council that an International Union of Geology be established and that it embrace the following specific aims:

1) to promote and encourage the study of geological problems;

2) to facilitate international co-operation in geology and related sciences;

3) to provide continuity in international co-operation in geology;

4) to assist the IGC, it being understood that the long established activities of the Congress shall be safeguarded.

Several Councillors continued to "wrestle with their consciences" but the majority voted to reconstitute the above-mentioned "working committee" as the Organizing Committee of the Union and charge it with the responsibility of preparing draft statutes. The Organizing Committee consisted of the following members:
N. Belyaevsky (USSR),
E. Clar (Austria),
J.A. Dons (Norway),
J.M. Harrison (Canada),
L. Hawkes (U.K.),
R. Lafitte (France),
K.A. Lindbergson (Sweden), Chairman,
V. Marmo (Finland),
T.B. Nolan (USA),
A. Noe-Nygaard (Denmark),
B.C. Roy (India),
H.M.E. Schürmann
(Netherlands),
W. Smulikowski (Poland),
T. Sorgenfrei (Denmark).

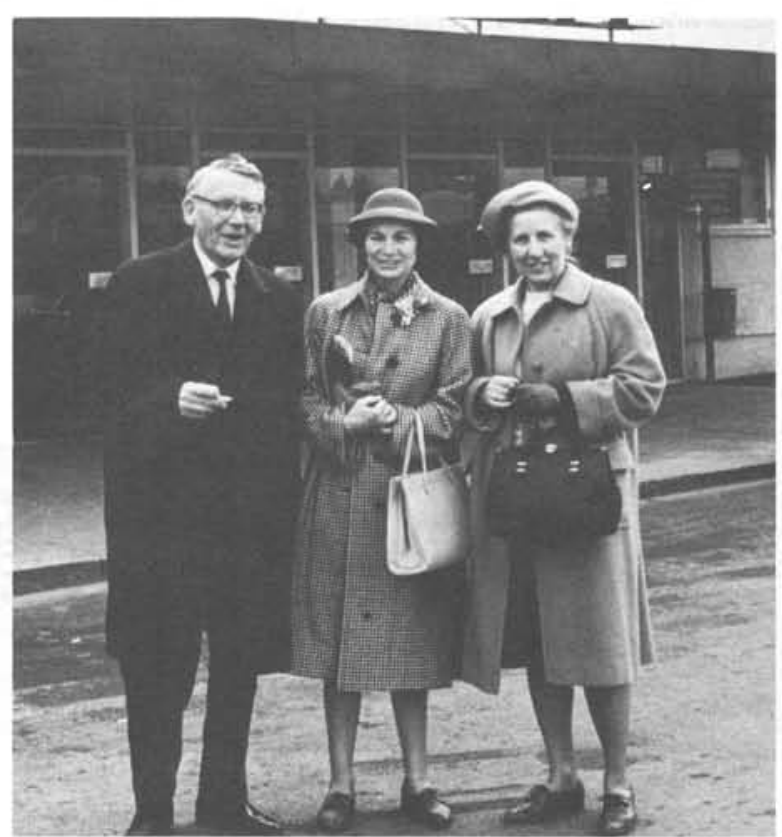

K.A. Lindbergson, Sweden, Chairman of the Organizing Committee that led to the founding of the International Union of Geological Sciences, shown here with his wife (extreme right) and Mrs. J.M. Harrison. 
The five members from the Nordic countries played a leading role on the Committee. On September 15, 1960, a letter was sent to all National or Contact Committees and Head Delegates requesting comments on the draft statutes submitted by the United Kingdom. The intention was to use these statutes and the comments as the basis for the Union's draft statutes which would later be submitted to the National Committees once again for acceptance or rejection. If accepted, a formal application was to be made for admission to ICSU by May 15, 1961 in order to be considered for membership at ICSU's General Assembly in 1961.

The Organizing Committee called a meeting in Stockholm on the 28th and 29th of December, 1960. (In the interim, the Nordic and USSR members had met in Finland to compile a discussion paper that could serve as a "spring board" for the meeting.) The Committee met under the auspices of the Royal Swedish Academy of Sciences and covered a wide-ranging agenda which included the formulation of statutes, the development of aims and objectives for the Union, and its general modus operandi.

While most Committee members were present or were represented by their designated substitutes, the absence of a representative from the National Committee of the USSR caused some apprehension. To ensure that no misunderstanding arose thereafter, Vladi Marmo (who spoke fluent Russian) took the precaution of contacting USSR by telephone, and the meeting went on smoothly. Committee members accepted Noe-Nygaard's view of geology as outlined in his opening address to the Norden Congress - that geology really represented a broad spectrum of sciences. They christened their fledgeling Union the International Union of Geological Sciences.

Setting what must surely be a world record for speed in international activities, the Secretary General of the Organizing Committee, Theo Sorgenfrei, circulated on January 2, 1961 the draft statutes and the report on the meeting, requesting countries to indicate their interest in adhering to the Union by March 15. He had even advanced the May 15 deadline to meet ICSU requirements and scheduled another formative meeting for early March.

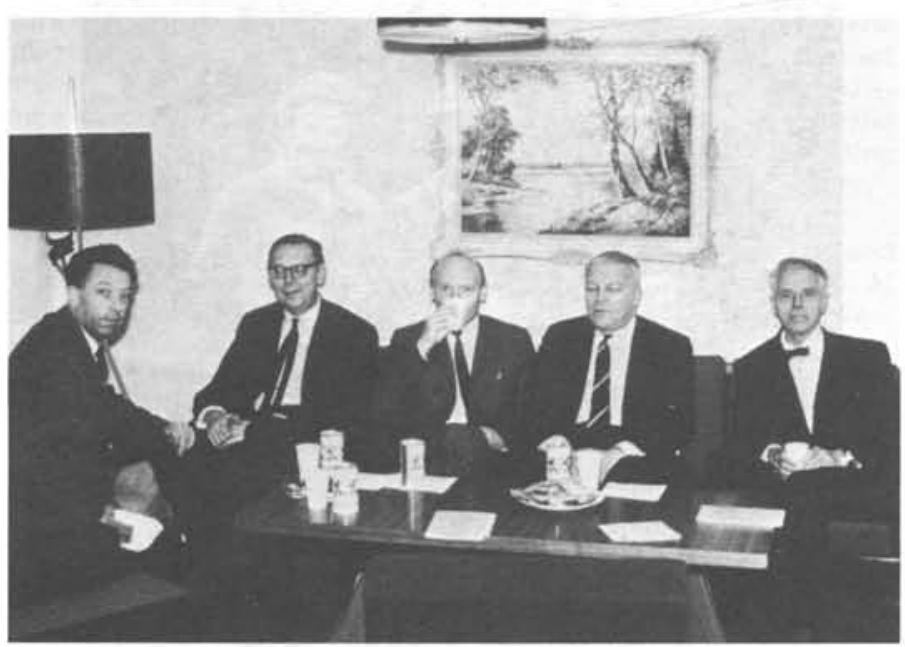

First Changeover of Executive Committee, Munich, 1965. Left to right: J.A. Dons (Norway)-outgoing Treasurer, $R$. Trümpy (Switzerland)-incoming Treasurer, T. Sorgenfrei (Denmark)-outgoing Secretary General, W.P. van Leckwijck (Belgium)-incoming Secretary General, and T.F.W. Barth (Norway)-incoming President.
The replies offered conclusive proof of the need for the geological union: between January 2 and March 1, 30 countries had applied for membership. The meeting that followed on the 2nd and 3rd of March, 1961, was held at Unesco House in Paris. Unesco's interest in supporting the formation of a geological union had never diminished: funds were provided to defray the cost of travel for some of the delegates and to help in the organization. ICSU was represented by Nicolai Herlofson, Secretary General, and George Laclavere, Treasurer; Unesco's spokesman was Victor Kovda, then Director of the Department of Natural Sciences and a direct "bureaucratic descendant" of Joseph Needham and Pierre Auger.

To digress for a moment, the records show that Professor Kovda had stressed at this meeting that independent non-governmental scientific organizations such as the IUGS could assist and promote the aims of Unesco: they could "supplement" the national scientific bodies that were part of Unesco. Many years later, when I was Assistant Director General for Science in Unesco (and a direct bureaucratic descendant myself of Needham, Auger and Kovda) the truth of his statement was brought home to me very forcefully indeed. The current International Geological Correlation Programme, jointly managed by Unesco and IUGS and with great success, is further evidence of Kovda's foresight.

\section{The Founding Fathers}

Unable to attend the sessions of March 2-3 in person, I was delightfully surprised and proud to learn that I had been elected, in absentia, the first President of IUGS. What pleased me even more was that Theo Sorgenfrei had beeri elected Secretary General. An intelligent, dedicated, and hard-working gentleman, Sorgenfrei performed his critical role with vigour and expertise.

Arne Noe-Nygaard served as de facto Past President of the Union because he had been President of the Norden Congress; he did much to develop the philosophical base of the Union. Johannes Dons from Norway was the first Treasurer. With three out of the four principal officers coming from the Nordic countries, it can hardly be said that Scandinavia was not given the opportunity to contribute to the Union's formative years! Moreover, KarlAlbert Lindbergson of Sweden, as Chairman of the Organizing Committee, played a key role in those early days, and the man "behind the scenes" quite often turned out to be Vladi Marmo of Finland, whose extraordinary knowledge of languages and infectious amiability kept matters on an even keel throughout. Both Marmo and Sorgenfrei died much too young (1969 and 1972 respectively) but they contributed a great deal and are remembered fondly.

Vice Presidents were also elected at the Paris meeting from regions of the world that were defined more or less on the basis of the geographical divisions of Unesco. They were Gorsky, USSR; Hawkes, U.K.; Kobayashi, Japan; Lamego, Brazil; Lombard, France; and Roy, India.

Once the statutes were accepted and the officers nominated, a formal application was sent to ICSU asking that IUGS be admitted as a general Union at ICSU's 9th General Assembly September $24-28,1961$. The Assembly concluded that IUGS was a direct descendant of the International Geological Congress, and that the normal five year waiting period could therefore be waived. IUGS was then unaminously admitted to ICSU. As official representatives of IUGS at the Assembly, Sorgenfrei, Dons and I had the honour of accepting ICSU's decision and its confirmation of IUGS' "rooțs" in the IGC. 


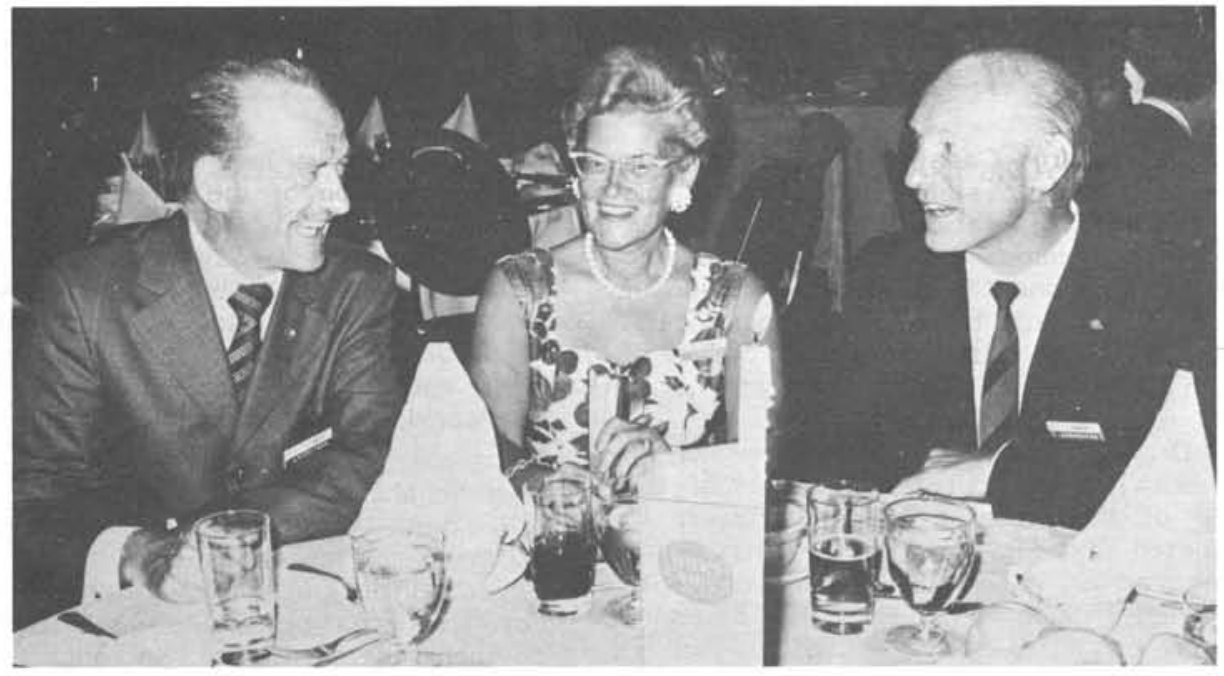

Meeting shortly before T. Sorgenfrei's death in 1972, are, left to right: J.M. Harrison, Mrs. K. Marmo (widow of V. Marmo) and $T$. Sorgenfrei.

What lay ahead was the difficult task of determining which activities should engage the immediate attention of the Union, which activities should be co-ordinated with other Unions, what affiliations should be accepted and what new organizations might be encouraged. A formal meeting of the IUGS Council was deemed necessary before the New Delhi IGC scheduled for 1964; this was held in Rome on the 14th and 15 th of October, 1963 under the auspices of the National Research Council of Italy. Decisions were taken on the byelaws of the Union, the rules for establishing the President and Vice Presidents, representation on ICSU and a host of other organizational and administrative matters; a full report was submitted to the Congress in Delhi.

One of the first major problems facing the Union's new Executive concerned the unforseen large number of organizations applying for affiliation with IUGS. If anything endorsed beyond all doubt the need for a Union to coordinate international geological activities in between Congresses, these applications did. But they also caused a greater drain on the fairly limited resources. It became necessary to define more closely the meaning of "independence" of IUGS financial sources and assistance. Of course, the question of money grew more acute with each Council meeting, and, word has it, the problem still plagues the Union.

Seventeen years have lapsed since the birth of IUGS. Its growth has been rapid and its work most useful. The present Council, I understand, hopes to consolidate the IUGS scientific program, to focus it on activities that promise the best opportunities to advance the cause of the geological sciences and to contribute to the welfare of mankind. Excellent initiative, and a formidable undertaking! And certainly no less of a challenge than those that faced the "founding fathers"'.
When I look back on the early days of IUGS, I sometimes think the first Executive was lucky. Everything was growing,countries and associations were quickly joining the Union. It pleased our sense of the fitness of things that IUGS should be so important and we left to our successors the problems of integration. Some of the details concerning the formation of the Union have grown hazy, but they are history anyway. What lives is the enthusiasm and the pride and the energy with which we tackled the opportunity to work on an international scale for the betterment of geology and for the countries we served. The memory of that rings clear as a bell.

\section{References Consulted}

International Geological Congress, Report of 18 th Session, Great Britain, 1948. Part 1, (Council Paper 10) p. 147148 ; p. 160-167.

International Geological Congress, Comptes rendus de la 19 ème Session, Alger, 1952. Session, Vol. 22, p. 215-238.

International Geological Congress, Report of 21st Session, Norden, 1960. Part 28, General Proceedings, Council Report, p. 226-233; p. 237-238; p. 245-248; Proceedings of the Bureau, p. 258-269.

IUGS Circular Letters, No's 1-7, 1961-1963.

"International Union of Geological Sciences, How it was born, What it is, How it works"; (Pamphlet, obtainable from Secretary General, IUGS).

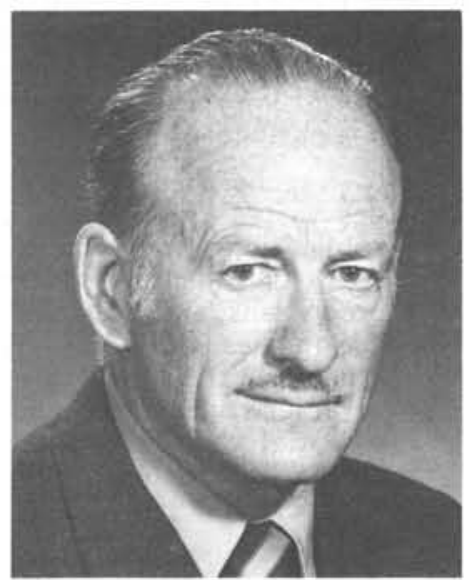

ABOUT THE AUTHOR: James Merritt Harrison's distinguished career in international science has included service as President of the International Council of Scientific Unions. From 1972 to 1976 he was Assistant Director General for Science at Unesco. Prior to that he was Senior Assistant Deputy Minister of Canada's Department of Energy, Mines and Resources and Director of the Geological Survey of Canada. Having recently co-authored a report entitled "The Management of Canada's Nuclear Wastes", Dr. Harrison has just been appointed Chairman of ICSU's Committee on Nuclear Waste Disposal. 